\title{
篩骨洞転移により判明した肝細胞癌の一症例
}

\author{
岩武 博也・堤 康一朗・渡来 潤次 \\ 大竹 英夫・竹山 勇
}

\section{A Case of Hepatocellular Carcinoma with Metastasis to the Ethmoid Sinus}

\section{Hiroya Iwatake, Kouichiro Tsutsumi, Junji Watarai, Hideo Ohtake and Isamu Takeyama}

(St. Marianna University School of Medicine)

Metastatic carcinoma to the nose and paranasal sinus are relatively rare. We reported a case of hepatocellular carcinoma with metastasis to the ethmoid sinus. A 56-year-old male complained of the left facial pain. Tomography and CT scanning of the paransal sinus showed abnormal shadows in the left ethmoid sinus. The histopathological examination of the tumor revealed hepatocellular carcinoma. The patient was treated with chemotherapy (MMC, 5-FU) and immunotherapy (OK-432), but died about 9 months later.

The possibility of metastatic carcinoma should be considered when diagnosing head and neck cancer.

Key words: metastatic carcinoma, ethmoid sinus, hepatocellular carcinoma

\section{緒言}

頭頸部領域の覀性腫焬は頸部リンパ節を除く とそのほとんどが原発性であり他蔵器からの転 移性腫晹の報告は少なく稀と言われこれまで の報告では原発部位として，腎癌からの転移が 最も多いとされている，肝細胞癌の頭頸部領域 への転移は比較的稀で, 本邦に括ける郝告例は 11例で鼻・副鼻腔に限ると3 例にすぎない，今 回，私達は肝細胞癌の節骨洞転移症例を経験し たので，その臨床経過について述べ併せて若干 の文献的考察を加光て報告与る。

$$
\text { 症例 }
$$

患者: 56 才, 男性.

初診：昭和159年2月17日。
主訴：左顔面痛.

家族歴: 父親が肺絬核，母親が卵巣腫瘍にて それぞれ死亡.

既往歴：顺和18年在外転神経障害.

珻和157年 鼻出血l.

㮌和58年 肝機能障害.

現病歴: 㮌和58年 9 月頃より左顔面痛出現し 近医耳鼻科受晾，精查钊められるもそのまま放 置. 昭和59年 1 月頃より左顔面痛は增強してき た.昭和59年 2 月 8 日, 頭頂部を鉄柱に打撲, 2 月 12 日朝より傾服状態となり近医内科受診, 浆 2 月13日当科内科紹介され入院となった。 入 院後, 頭部 CTを施行したが特に異常なく, 左 顔面痛精查のため 2 月 17 日当科紹介となった。

玨マリアンナ医科大学耳鼻咽喉科学教窒 
現症：体格中等度, 球結膜に貧血, 黄㾝なし。 意識は傾汇傾向. 腹部は右季肋部に肝を 1 横指 触知, 表面平滑, 弾性硬で腹水は認められなか った．神経学的所見は左三叉神経第 2 枝領域の 疼痛と右外転神経障害を認めた。腱反射は異常 を認めなかった。

耳鼻科所見：前鼻鏡所見にて，中鼻道，中甲 介は正常. 鼻咽腔ファイバーにて中甲介後方下 端から上咽頭側壁にかけて内方より压排された ような腫脹を認めた。頸部は左上深頸部リンパ 節領域に $3 \mathrm{~cm}$ 大のリンパ節を触知し圧痛を認 めた。

入院時検查所見 :

血液 ; RBC 451万, $\mathrm{Hg} 14.4 \mathrm{~g} / \mathrm{dl}$, Hct 43.2 $\%$, 血沈 $92 \mathrm{~mm} / 119 \mathrm{~mm}$, CRP $(1+)$, T. P $8.1 \mathrm{~g} / \mathrm{dl}, \mathrm{A} / \mathrm{G}$ 比 0.74, T. Bil $1.0 \mathrm{mg} / \mathrm{dl}$, GOT $35 \mathrm{mU} / \mathrm{ml}$, GPT $64 \mathrm{mU} / \mathrm{ml}$, LDH 343 $\mathrm{mU} / \mathrm{ml}$, ALP $206 \mathrm{mU} / \mathrm{ml}$, LAP $46 \mathrm{mU} / \mathrm{ml}$, $\gamma$-GTP $19 \mathrm{mU} / \mathrm{ml}$, ChE $0.5 \triangle \mathrm{pH}, \mathrm{HBs}$ 抗原 (一), HBs 抗体 (一) と軽度の炎症所見と GOT, GPT の軽度の上昇が認められ，その他 電解質，腎機能は異常を認めなかった。

㖪液; 比重 1.005, PH 7.5, 細胞数 $8 / 3$ (単核 の夕), 総蛋白 $21 \mathrm{mg} / \mathrm{dl}$, 糖 $59 \mathrm{mg} / \mathrm{dl}, \mathrm{Cl} 119$ $\mathrm{mEq} / \mathrm{l}$

結過：2月 17 日副鼻腔断層撮影施行し（図 1 ), 左篩骨洞に均一な陰影と後頭篩骨洞の側壁 と下壁に骨破壊像が認められた。続いて副鼻腔 CTを施行し（図 2）左篩骨洞から蝶形洞，翼

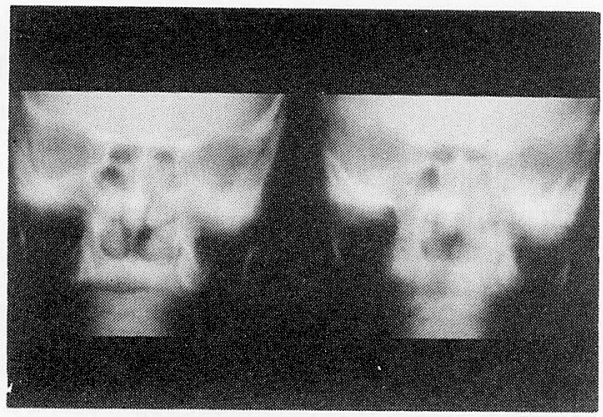

図 I 副鼻腔断層撮影

左篩骨洞に㓌影と後部篩骨洞の骨破壊像を認める.
口蓋窩にかけて骨破壊を伴ら陰影が認められ た. 以上の結果より左後頭篩骨洞の悪性腫痬が 疑われ，2月22日局所麻酔下にて試験的鼻内節 骨洞開放術を施行した。術中所見では後部篩骨 洞下部より膨隆した弾性硬の易出血性の腫瘍が 認められた。その際の病理組織像は, 弱拉大

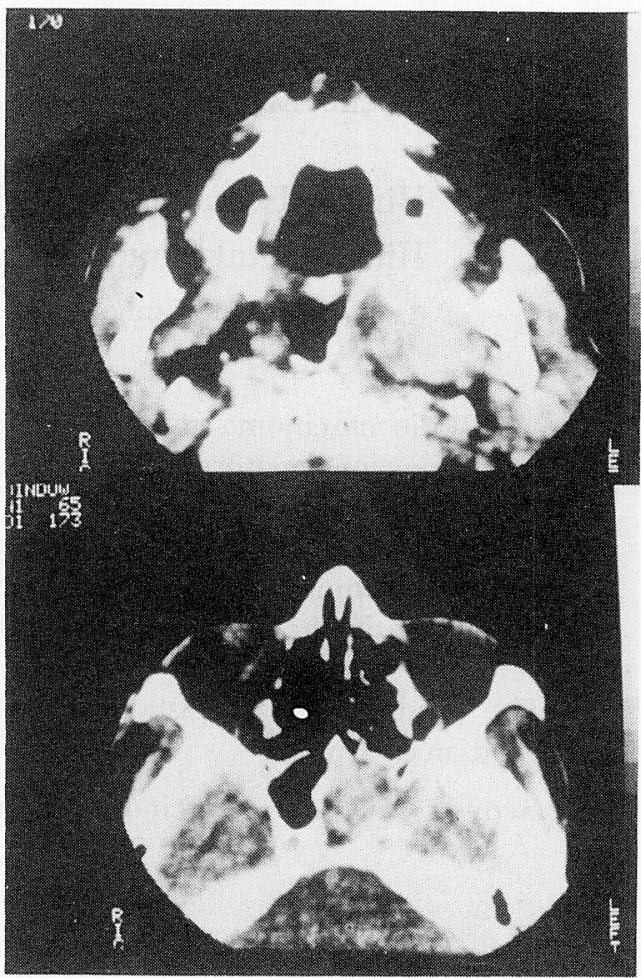

図 2 副鼻腔 CT

左篩骨洞から蝶形洞，翼口蓋窝にかけて骨破填 を伴う腫瘍を認妙る。

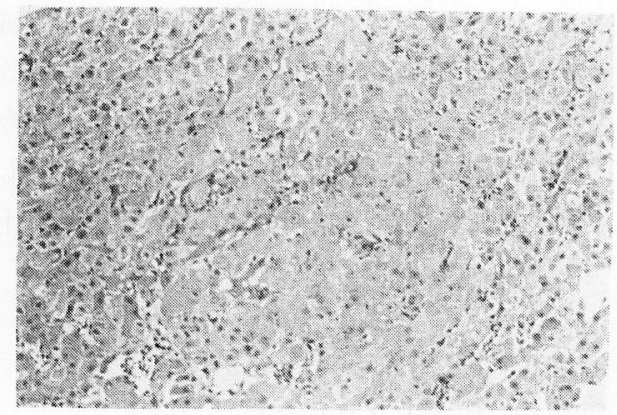

図 3 病理組織（弱拡大）

腫瘍細胞は索状に配列し間質成分は乏しい。 


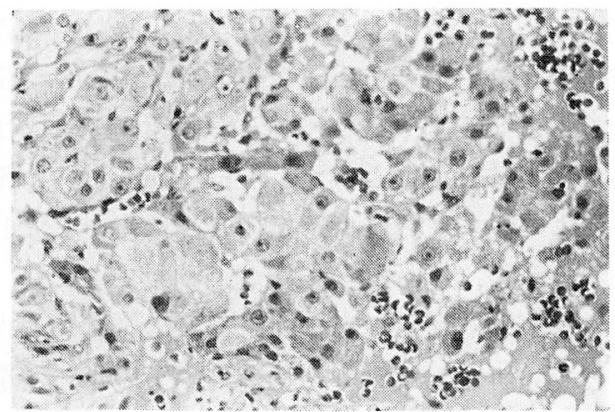

図 4 病理組織（強拡大）

腫瘍細胞は好酸性の豊富な細胞質を持ち, 比較的大きな核小体を認める。

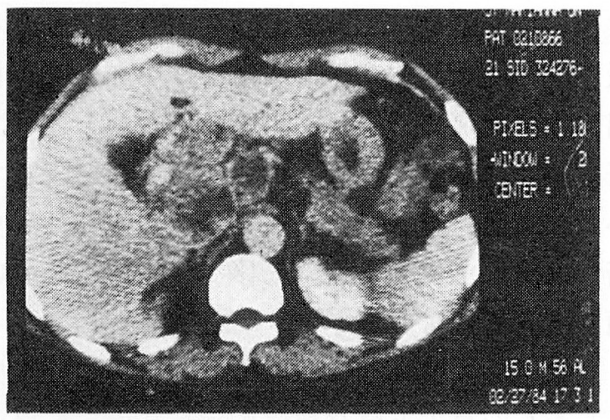

図 5 腹部 $\mathrm{CT}$

肝門部に多発性の肝細胞癌を認める。

（図 3 ）では腫瘍細胞は索状に配列し間質に之 しくその中に小さな血管が認められた：強拡大 （図 4 ）では個々の腫瘍細胞は好酸性の豊富な 細胞質を持ち，核は比較的大きく明瞭な核小体 が認められ，分化度の良い Edmondson II 型 の肝細胞癌と診断された。その結果より 2 月 27 日腹部 CT を施行したところ（図 5 ) 肝門部 に多発性の腫瘍を認め, 経静脈的造影後の CT にて (図 6) 中心が low density の壞死性変化 を認める肝細胞癌が確認され，以上より本症例 は肝細胞癌の算骨洞転移と診断された。 この頃 より GOT, GPT は徐々に上昇し, AFP 68.3 $\mathrm{ng} / \mathrm{ml}$ であった。 3 月 7 日全身骨シンチ施行 し（図 7 ）左篩骨洞，第 4 胸椎，第 5 腰椎に集 積を認めた。 3 月13日より化学療法 (MMC, 5$\mathrm{FU})$, 免疫療法 $(\mathrm{OK}-432)$ を開始, 左顔面痛は 徐々に改善を認めたが，右季肋部に肝を 4 横指

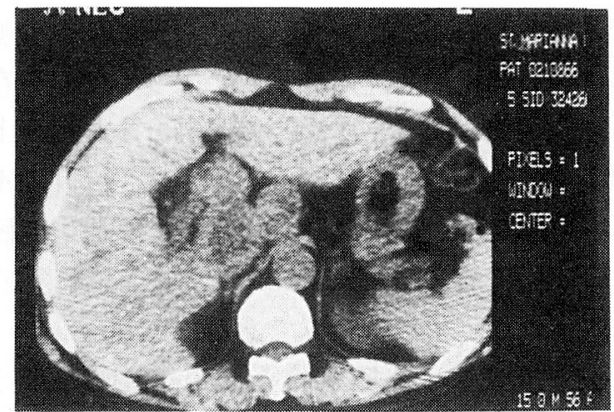

図 6 経静脈的造影後腹部 $\mathrm{CT}$

中心が low density で壊死性変化を伴う 肝細胞癌を認める。

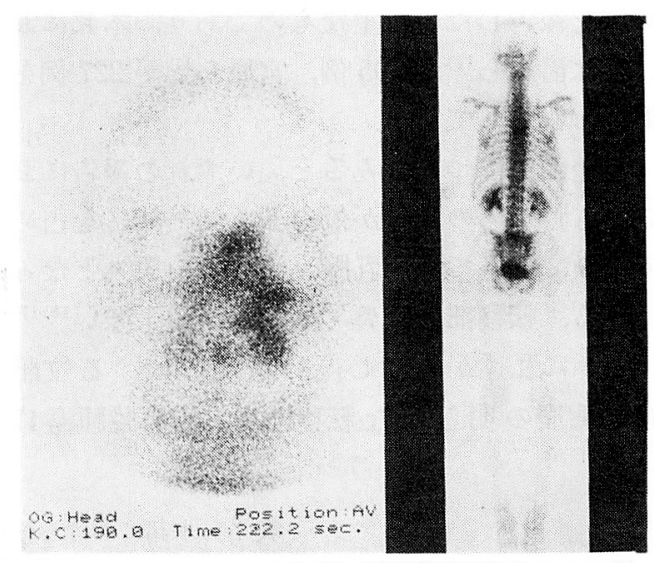

図 7 全身骨シンチ

左篩骨洞，第 4 胸椎，第 5 腰椎に集積を認める.

触知するようになり，GOT $135 \mathrm{mU} / \mathrm{ml}, \mathrm{GPT}$ $107 \mathrm{mU} / \mathrm{ml}$, AFP $136.7 \mathrm{ng} / \mathrm{ml}$ と高值を示し た. 3 月28日本人の希望により退院. その後他 院にて死亡, 残念ながら剖検は行な党なかっ た.

\section{考察}

肝細胞癌は転移を来しやすい腫瘍に属し，一 般に肝細胞癌の転移率は宮地ら ${ }^{1)} 474.1 \%$, 山 口ら 2 は $64 \%$ ，荒木ら ${ }^{3)}$ は $66 \%$ と報告してお。 り, また転移形成では血行性転移, リンパ行性 転移, 直達性転移いずれも起こしうるが血行性 転移が最も多いと言われている，血行性転移の 中では肺への転移頻度が最も高く, 宮地らは 43.2\%, 山口らは51.6\%, 荒木らは $41.1 \%$ と報 
告して扣り以下副腎，骨と続き，頭頸部への転 移は極めて稀で私達の検索した限りでは, 現在 まで今井の ${ }^{4)}$ 眼窩, 中田 ${ }^{5)}$ の眼窩, 小林6) 顎洞, 佐野 ${ }^{7)}$ の眼窩, 福山 ${ }^{8)}$ の鼻尖部 (詳細不 明), 田中 ${ }^{9)}$ の眼窩, 船井 ${ }^{10)}$ の扁桃, 宮原 ${ }^{11)}$ の硬 口蓋, 歯肉の 2 例, Nishioka ${ }^{12)}$ の上顎洞後部, 後藤 ${ }^{13)}$ の眼窩で11例のみである.

一方頸部リンパ節を除く頭頸部領域におけ る他臓器からの転移性腫瘍の報告は 1872 年 Perls ${ }^{14)}$ が気管支癌の蝶形洞転移を報告したの が最初で, その後 Friedman ${ }^{15)}$ が自験例 8 例 を含む64例，Bernstein ${ }^{16)}$ が自験例10例を含む 82例を報告したのが主なものであり，本邦にお いては溝尻ら ${ }^{17)}$ が 105 例, 宮原ら ${ }^{11)}$ が 227 例を 集計し報告している。

原発部位についてみると，いずれの報告にお いても腎からの転移が最も多く30-50\%を占め て扣り，続いて肺，乳腺，消化管，睪丸となっ ている。転移部位は鼻・副鼻腔が最も多(16)17) 表 1 に私達が検索し得た本邦に扣悩る文献 的に病歴の明らかな転移性鼻・副鼻腔腫痬 17
例6)1112)17 30)を示した．原発部位はやはり腎が 17 例中 8 例と最多で以下睪丸 3 例, 肝 2 例, 肺, 繊毛上皮，大腸，乳腺がそれぞれ 1 例となって いる。転移部位について Bernstein は上顎洞 が最も多いと言っているが，私達の集計した 17 例では鼻腔，篩骨洞，上顎洞の順であった。

症状に関しては，鼻出血，局所の腫脹，鼻閉 などを主訴としており転移性腫瘍としての特徵 的な症状はないが，原発腫瘍別で見ると腎癌か らの転移 8 例中 6 例は鼻出血を主訴としてい る.これは腎癌は組織学的に血管豊富なためだ と言われている2126)27)29)。肝細胞癌の場合も自 験例の手術所見にて易出血性であったように, 後藤 ${ }^{13)}$ らは 4 例中 3 例に手術操作を加えたが易 出血性で腫瘍全摘出が不可能であったと述べ, 肝細胞癌は転移部位において子類洞を形成して いるためと考察している，またその他では，宮 崎 ${ }^{211}$ は乳癌, 気管支癌の転移では煩部痛が多い 傾向にあると言っている.

次に原発部位, 転移部位のどちらの症状が先 行したかを見ると原発部位先行が 9 例, 転移部

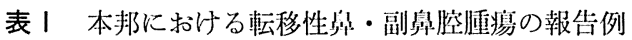

\begin{tabular}{|c|c|c|c|c|c|c|c|c|}
\hline \multicolumn{2}{|c|}{ 症例|年跉| } & 性 & 転 移 部 位 & 原発部位 & 訴 & 症状の先行 & \multicolumn{2}{|c|}{ 報告者（年度） } \\
\hline 1 & 41 & 男 & 上顎洞 & 肝 & 鼻閉, 複視, 眼周囲重圧感 & 転移 & 小 林 & $(1951)^{6)}$ \\
\hline 2 & 68 & 女 & 篩骨洞 & 腎 & 鼻出血 & 原発 $(48 \mathrm{M})$ & 河 合 & $(1958)^{18)}$ \\
\hline 3 & 48 & 男 & 鼻腔, 上買洞, 篩骨洞 & 腎 & 鼻出血, 鼻閉, 視力障害 & 転移 & 浅 井 & $(19$ \\
\hline 4 & 55 & 男 & 鼻腔 & 腎 & 鼻出血, 鼻閉, 貧血 & 原発 $(60 \mathrm{M})$ & 黒 田 & )$^{20)}$ \\
\hline 5 & 29 & 男 & 上顎洞 & 䉅丸 & 煩部腫脹, 眼球突出 & 転移 & 宮＼cjkstart崎 & 9) $)^{21)}$ \\
\hline 6 & 29 & 女 & 鼻腔 & 找上皮 & 部腫瘤 & 原発 $(24 \mathrm{M})$ & 川 本 & $0)^{22)}$ \\
\hline 7 & 66 & 男 & 鼻腔, 耳下腺 & 腎 & 鼻出血, 耳下腺腫脤 & 原発 $(15 \mathrm{M})$ & 里 見 & )$^{23)}$ \\
\hline 8 & 51 & 男 & 蝶形洞 & 腎 & 複視, 視力障害 & 転移 & 中 島 & 3) \\
\hline 9 & 74 & 女 & 鼻腔, 篩骨洞 & 腎 & 鼻出血 & 原発 $(31 \mathrm{M})$ & 山 本 & )$^{25)}$ \\
\hline 10 & 31 & 男 & 篩骨洞 & 箪丸 & 眼理 & 転移 & 溝 尻 & )$^{17)}$ \\
\hline 11 & 62 & 男 & 前頭洞, 篩骨洞 & 粲 & 眼理 & 転移 & 石＼cjkstart㥓 & 1) $)^{26)}$ \\
\hline 12 & 58 & 男 & 鼻腔 & 大腸 & 鼻腔内腫瘤，顎下部腫脹 & 原発 $(12 \mathrm{M})$ & 雑 賀 & $(1982)^{27)}$ \\
\hline 13 & 37 & 女 & 蝶形洞 & 乳腺 & 難聴, 頭痛 & 原発 $(72 \mathrm{M})$ & 宮 本 & $(1982)^{28)}$ \\
\hline 14 & 64 & 男 & 鼻腔, 上顎洞 & 腎 & 奥出血L & 転移 & 長谷川 & $(1982)^{29)}$ \\
\hline 15 & 44 & 男 & 篩骨洞, 前頭洞, 眼窩 & 睪丸 & 眼瞼腫脤, 眼球突出 & 原発 $(36 \mathrm{M})$ & 金 成 & $(1983)^{30)}$ \\
\hline 16 & 79 & 男 & 鼻腔 & 肺 & 鼻出血向 & 原発 $(1 \mathrm{M})$ & 宮 原 & $(1983)^{11)}$ \\
\hline 17 & 50 & 男 & 上顎洞後部 & 肝 & 顔面痛 & 転移 & & \\
\hline
\end{tabular}

（）は原発部位の症状が先行した場合の転移部位の症状発現までの期間 単位；月 
位先行が 8 例となっており Willis ${ }^{31)}$ の言う latent primary carcinoma, つまり原発部位の 発育が緩慢で，その症状が現われないらちに転 移部位の症状が先行する場合が約半数を占め大 変興味深い点と思われる。 また原発部位の症状 が先行した場合，転移部位の症状の発現するま での間隔は 1 か月から 6 年とさまざまである。 特に腎癌では原発腫瘍摘出後数年を経て鼻・副 鼻腔に転移する事が多い上うで，Eneroth ${ }^{32)}$ は，術後13年目に上顎洞に転移した症例を報告 している。一般的にも腎癌は転移により発見さ

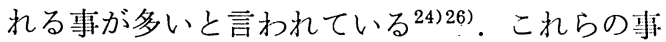
より全身所見も注意深く観察し，既往歴など問 診を良く聴取する事が必要と思われる。

鼻・副鼻腔への転移経路は, Nahum, Bailey ${ }^{33)}$ と Batoson ${ }^{34)}$ による Vertebral Venous Plexus を介するものがあり，これには弁が存在しない ため胸腔内圧, 腹腔内压が上昇した時容易に腫 瘍細胞が移動し腫瘍栓塞を形成し, 翼状静脈叢, 海綿状静脈叢に到達し逆行性に転移与る経路と 門脈より下大静脈，右房，右心，肺を介する経 路の 2 つが考えられる。本症例では胸部レ線転 移は認められないため前者の経路が考光易いが 推测の域を脱しない.

\section{結 語}

今回私達は左顔面痛を主訴として X-P 所見, 術中所見，病理組織所見にて肝細胞癌の篩骨洞 転移と診断した症例を経験した。本例は本邦に 扣いて肝細胞癌の頭頸部領域への転移では12例 目，中でも鼻・副鼻腔への転移に限ると 4 例目 にあたると思われた，本症例の如く転移部位の 症状が原発部位の症状に先行する場合も少なく ないので，頭頸部領域においても腫瘍性病変を 診察した時は全身所見を注意深く観察し，転移 性腫楊の可能性を常に念頭に置く必要があると 思われた。

なお，本論文の要旨は第50回日耳鼻神奈川県地方会 部会にて発表した。

\section{参考文献}

1）宮地 徽, 他：10年間（1964－1955）におおけるわ
が国の肝癌剖検 639 例の病理学的研究. 肝藏 1: 101, 1960.

2 ）山口龍介, 他 : 原発性肝癌の病理形態学的研究. 久医誌 $41 ： 947 \sim 969,1978$.

3 ）荒木嘉隆, 他 : 原発性肝癌一日本人肝癌の臨床統 計的研究一. 日本臨床 32 : 夏季增; 2231 2262 1974.

4) 今井 亮: 肝臓二原発セル転移性腿窝癌腫二就 テ. 日眼 $45: 353 \sim 355,1941$.

5 ）中田良三 : 肝蔵癌の眼窩内転移症例. 眼臨 41 : 38, 1947.

6 ）小林秀夫：上頂洞に転移せるへパトームの稀有な る1例. 日耳鼻 $54: 184 \sim 187,1951$.

7 ）佐野正純：肝臟癌より転移せる眼窩腫瘳。眼臨 $54: 845 \sim 848,1960$.

8 ）福山和彦，他：臬尖部に転移をきたした肝臟癌症 例および頭頸部領域の転移癌について。目系 $72: 1111,1969$.

9 ）田中耕一：眼球突出を主訴とした原発性肝癌の一 剖検例. 耳鼻臨床 71 ：655 660, 1978.

10）船井洋光, 他：転移性扁桃腫瘍の 1 例. 耳喉 53 : 421 423, 1981.

11）宮原 裕, 他：頭頸部領域への転移癌 6 例の経験 と文献的考察. 日耳鼻 86 : 951 957, 1983.

12) Nishioka $K$, et al: Hepatoma metastasizing to the retromaxillary region with initial otologic manifestation. Hiroshima J Med Sci 32 : 407 411, 1983.

13）後藤まゆき，他：肝細胞癌の眼窩内転移の 1 例. 耳鼻臨床 79: 253 257, 1986.

14) Perls $M$ : Beitrage Zur Geshwulstlehre. Virch Arch 56: 437, 1872.

15) Friedman $I$, et al: Metastatic tumors in the ear, nose, and throat region. J Laryng Otol 79 : 576 591, 1965.

16) Bernstein J. M, et al: Metastic tumors to the maxilla, nose, paranasal sinus. Laryngoscope $76: 621 \sim 650,1966$.

17）滥尻源太郎，他：転移性館学洞精上皮腫の 1 例. 耳喉 52：1053 1057，1980.

18）河合純一郎，他：穊骨蜂策に発生せる Hypernephrom の 1 例. 日耳鼾 $61: 315 ， 1958$.

19）浅井良三，他：臬腔，副楀腔転移により発見され 
た Grawitz 腫焬の 1 例. 耳奥臨床 53:939 947, 1960.

20）黑田道弘, 他：鼾内転移を若起せる Grawitz 腫 瘍. 耳鼻臨床 60:109 112, 1967.

21）宮崎泰一，他：上顎洞に転移した精上皮腫の 1 例. 広医誌 $22: 1147 \sim 1151,1969$.

22）川本 智，他：鱼腔転移を来した䋐毛上皮媑の 1 例. 耳鼻臨床 63:481 488, 1970.

23）里見佳昭, 他：腎癌の耳鼻咽喉科領域（耳下腺, 鼻腔, 舌, 歯肉) への転移症例. 臨泌 28:611 616, 1974.

24）中島成人，他：蝶形洞および多発性骨転移を来し た腎癌例. 耳鼻 24 : 198 204, 1978.

25）山本誠，他：重篤鼻出血を主訴とした腎癌 (Grawitz腫瘍)の宜・副鼻腔転移症例. 耳娭 52: - 323 327, 1980.

26）石峆孝览，他：腿球突出を主訴とした腎癌の 1 症 例. 眼臨医 75:2068 2071, 1981.

27）雑賀 宏，他：息腔転移をきたした大腸癌の 1 症 例. 耳鼾臨床 $75: 795 \sim 800,1982$.

28）宮本浩明，他：乳腺腫瘍の遅延型蝶形骨洞壁転移
症例. 耳嶴臨床 $75: 2559 \sim 2565,1982$.

29）長谷川潤，他：鼻・副覍腔転移により発見された 腎細胞癌の 1 例. 臨泌 36: 461 464, 1982.

30）金成拓二，他：左睪丸に原発し眼窝および篩骨 洞，前頭洞に転移したと思われる Seminoma の 1 例. 眼紀 34: 1817 1827, 1983.

31) Willis RA: The spread of tumors in the human body. Butterworth Co. Ltd, London, 1952.

32) Eneroth CM : Profuse epistaxis in hypernephroma metastases. Acta Otolaryngol 53: 546 550, 1961.

33) Nahum AM and Bailey J : Maligorant tumors metastatic to the paranasal sinuses. Laryngoscope $73:$ 942 953, 1963.

34) Batoson OU: The Function of the vertebral veins and their role in the spread of metastases. Ann Surg 12: 138, 1940.

$\left(\begin{array}{l}\text { 別刷請求先 : 岩武博也 } \\ \text { 干213 川崎市宮前区督生2-16-1 } \\ \text { 聖マリアンナ医科大学耳鼻咽喉科学教室 }\end{array}\right)$ 